\title{
THE SMALL BUT SIGNIFICANT AND NONTRANSITORY INCREASE IN PRICES (SSNIP) TEST
}

Niminet Liviana, Assistant

UNIVERSITY OF BACĂU

\begin{abstract}
:
The Small but Significant Nontransitory Increase in Price Test was designed to define the relevant market by concepts of product, geographical area and time. This test, also called the „,hypothetical monopolistic test” is the subject of many researches both economical and legal as it deals with economic concepts as well as with legally aspects.
\end{abstract}

In competition law cases consisting of abuse of dominance or merging manners allegations the SSNIP test is crucial.

The SSNIP is most used to define a "relevant market"(which is commonly defined as "something worth monopolizing". This test is designed to avoid ad hoc debates about what products compete with each other, based, for example, on product characteristics. With the help of SSNIP test a market can be defined by all its three dimensions: product, geographical area and time.

The relevant market is composed of a 'catalogue' of goods and/or services which are considered substitutes by the customer. Now the question rising is why is such a catalogue worth monopolizing. The answer is that is worth monopolizing because if it is provided by only one supplier, that supplier could profitable increase its price without its customer turning away and choosing other goods and services from other suppliers.

\section{Economic perspective}

The SSNIP test was first introduced by the US Department of Justice Merger Guidelines in 1982. It was then a new method for defining markets and for measuring directly market power .Ten years later this test was used for the first time in EU in the Nestle vs Perrier case and has been officially recognized by the European Commission on its "Commission's Notice for the Definition of Relevant Market" in 1997.

The goal of SSNIP test is to identify the smallest relevant market within which hypothetical monopolist or cartel could impose a profitable significant increase in price. The governmental procedure of applying the test involves talking to people who make buying decisions. The question asked is whether such a monopolist or cartel could profit from a price increase of $5 \%$ for at least one year with the assumption that the terms of sale of all other products are held constant". If sufficient numbers of buyers are likely to switch to alternative products and the lost sales would make such price increase unprofitable, then the hypothetical market should not be considered a relevant market for the basis of litigation or regulation. Another, larger basket of products is proposed for a hypothetical monopolist to control and the SSNIP test is performed on that relevant market.

The empirical estimation of the critical elasticity of demand is one of the ways the SSNIP test can be applied. If the demand is linear, information on firms' price cost margins is sufficient for calculation. In the case of a pre-merger elasticity of demand that exceeds the critical elasticity, the decline in sales arising from the price increase will be sufficiently large to render the price increase unprofitable and the products concerned do not constitute the relevant market.

An alternative method for applying the SSNIP test where demand elasticities cannot be estimated, involves estimating the "critical loss." The critical loss is defined as the maximum sales loss that could be sustained as a result of the price increase without making the price increase unprofitable. Where the likely loss of sales to the hypothetical monopolist (cartel) is less than the Critical 
Loss, then a 5\% price increase would be profitable and the market is defined.

Basically, the test consists on observing whether a small increase in price (in the range of 5 to 10 percent) would provoke that a significant number of consumers switch to another product (in fact, substitute product). In other words, it is designed to analyse whether that increase in price would be profitable or if, instead, it would just induce substitution, making it unprofitable.

In general, one uses databases from the firms which may include data on variables such as costs prices, or sales and over a sufficiently long period (generally over at least two years).

In economic terms, what the SSNIP test does is to calculate the residual elasticity of firm's demand. That is, how does the firm price change by affect its own demand.

According to that test, product $\mathrm{X}$ is a relevant market if a profit maximizing hypothetical monopolist of product $\mathrm{X}$ could impose a small but significant, nontransitory increase in price (SSNIP) above the current prices of the brands of product X. For example we consider Coca-Cola Company and PepsiCo that are substitutes to some degree. Cola would be a relevant market if a hypothetical monopolist of Cola would raise the prices of Coca-Cola and Pepsi, at least a SSNIP.

Economic theory predicts that any profit-maximizing firm will set its prices at a level where demand for its products is elastic. Thus, when a monopolist sets its prices a monopoly level it may happen that two products appear to be close substitutes whereas at competitive prices they are not. This is a problem that many economists have noted as an important pitfall in the use of demand elasticities when inferring in both the market power and the relevant market. Plain said, the SSNIP test may have the downside that when using it, one cam define the relevant market too broadly, including products that are not substituible.

\section{Legal perspective}

The "Commission's Notice for the Definition of Relevant Market" has the purpose of providing guidance as to how the Commission applies the concept of relevant product and geographic market in its ongoing enforcement of Community competition law, especially the application of Council Regulation No.17 and (EEC) No 4064/89, their equivalents in other sectorial applications such as transport, coal and steel, and agriculture, and the relevant provisions of EEA Agreement and the ECSC Treaty.

The Commission's interpretation of 'relevant market' is without prejudice to the interpretation which may be given by the Court of Justice or the Court of First Instance of the European Communities.

The Regulations based on Article 85 and 86 of the Treaty, in particular in section 6 of Form A/B with respect to Regulation No 17 , as well as in section 6 of Form $\mathrm{CO}$ with respect to Regulation (EEC) No 4064/89 on the control of concentrations having a Community dimension have laid down the following definitions, "Relevant product markets" are defined as follows:

"A relevant product market comprises all those products and/or services which are regarded as interchangeable or substitutable by the consumer, by reason of the products' characteristics, their prices and their intended us".

Conceptually, this approach means that, starting from the type of products that the undertakings involved sell and the area in which they sell them, additional products and areas will be included in, or excluded from, the market definition depending on whether competition from these other products and areas affect or restrain sufficiently the pricing of the parties' products in the short term.

Generally, and in particular for the analysis of merger cases, the price to take into account will be the prevailing market price. This may not be the case where the prevailing price has been determined in the absence of sufficient competition. In particular for the investigation of abuses of dominant positions, the fact that the prevailing price might already have been substantially increased will be taken into account.

The assessment of demand substitution entails a determination of the range of products which are viewed as 
substitutes by the consumer as it is stated in the Paragraph 14 of the European Commission's Notice on the Definition of the Relevant Market for the Purposes of Community Competition Law. The Notice then proposes the so-called "SSNIP" test, which makes it possible to determine whether particular products are within the same market.

The SSNIP test, which was first introduced by the US Department of Justice and the Federal Trade Commission in analyzing horizontal mergers, legally works as follows: Suppose that a producer of a hypothetical product (e.g.-only for theoretical purpose-, butter) were to introduce a small but significant non-transitory increase in price. In those circumstances, would customers be inclined to switch their purchases to other producers of butter, or even to producers of another product - margarine, for examplewhich could serve as a substitute to butter? If the answer is yes, this suggests that the producer of butter operates in a market that is wider than just butter - one that comprises not only butter, but also the substitute product, margarine. A wider market makes it less likely that a merger of butter suppliers would reduce competition and raise prices to the detriment of customers. The presence of margarine suppliers will competitively constrain the price of butter even after such a merger. The same test can be applied to the delineation of the geographic market: if the price of butter in France were raised by a small but significant amount, would customers switch to suppliers in Germany? If a firm could raise its price by a significant amount and retain its customers, this would mean that the market would be worth monopolizing: prices could be raised profitably, since there would be no competitive constraint. For this reason, law researchers, refer to the SSNIP test as the "hypothetical monopolist test."

The hypothetical monopolist test is given formal expression in Paragraph 17 of the EC's Notice, where it states that:

"The question to be asked is whether the parties' customers would switch to readily available substitutes or to suppliers located elsewhere in response to a hypothetical small (in the range $5 \%$ to $10 \%$ ) but permanent relative price increase in the products and areas being considered. If substitution were enough to make the price increase unprofitable because of the resulting loss of sales, additional substitutes and areas are included in the relevant market."

This would be done until the set of products and geographical areas is such that small, permanent increases in relative prices would be profitable. The equivalent analysis is applicable in cases concerning the concentration of buying power, where the starting point would then be the supplier and the price test serves to identify the alternative distribution channels or outlets for the supplier's products. In the application of these principles, careful account should be taken of certain particular situations as described within paragraphs 56 and 58 [p.56: There are certain areas where the application of the principles above has to be undertaken with care. This is the case when considering primary and secondary markets, in particular, when the behaviour of undertakings at a point in time has to be analysed pursuant to Article 86. The method of defining markets in these cases is the same, i.e. assessing the responses of customers based on their purchasing decisions to relative price changes, but taking into account as well, constraints on substitution imposed by conditions in the connected markets. A narrow definition of market for secondary products, for instance, spare parts, may result when compatibility with the primary product is important. Problems of finding compatible secondary products together with the existence of high prices and a long lifetime of the primary products may render relative price increases of secondary products profitable. A different market definition may result if significant substitution between secondary products is possible or if the characteristics of the primary products make quick and direct consumer responses to relative price increases of the secondary products feasible], [p.58 : From a practical perspective, the concept of chains of substitution has to be corroborated by actual evidence, for instance related to price interdependence at the extremes of the chains of substitution, in order to lead to an 
extension of the relevant market in an individual case. Price levels at the extremes of the chains would have to be of the same magnitude as well.]

A word of caution on the hypothetical monopolist test: a monopolist may already be charging a monopoly price. If it raises its price further, its customers may switch to alternative products. In this situation, the monopolist's "own-price elasticity"-the extent to which consumers switch from its products in response to a price increase-is high. If a SSNIP test is applied between the monopolized product and another product, it might suggest a high degree of substitutability, since consumers are already at the point where they will cease to buy from the monopolist. The test would therefore exaggerate the breadth of the market. This error was committed by the US Supreme Court in United States vs. EI du Pont de Nemours and Co. (351 US 377 (1956)) in a case concerning packaging materials, including cellophane. It has since been known as the "Cellophane Fallacy". In this case, Du Pont (a cellophane producer) argued that cellophane was not a separate relevant market since it competed with flexible packaging materials such as aluminum foil, wax paper and polyethylene. The problem was that $\mathrm{Du}$ Pont, being the sole producer of cellophane, had set prices at the monopoly level, and it was at this level that consumers viewed those other products as substitutes. Instead, at the competitive level, consumers viewed cellophane as a unique relevant market (a small but significant increase in prices would not have them switching to goods like wax or the others). In the case, the US Supreme Court failed to recognise that a high ownprice elasticity may mean that a firm is already exercising monopoly power. This clearly demonstrates the care that must be taken in applying the SSNIP test. It may be appropriate in merger cases, where a competition authority is trying to predict what will happen in the future if the hypothetical monopolist were to raise its prices after the transaction; but not in a dominance case, where a crucial issue is whether the defendant is a monopolist in the first place.

\section{References:}

[1] Bishop, Simon; Walker, Mike. The Economics of EC Competition Law. London, Sweet and Maxwell, 1999;

[2] Motta Masimo, Competition policy, Theory and practice, Cambridge University Press 2004;

[3] Serge X. Moresi, Steven C. Salop and John R. Woodbury, Implementing the Hypothetical Monopolist SSNIP Test With Multi-Product Firms, www.antitrustsource, feruary 20008;

[4] COMMISSION NOTICE on the definition of relevant market for the purposes of Community competition law (97/C 372/03) 